\title{
MANGUE'S SCHOOL OU POR UMA PEDAGOGIA RIZOMÁTICA
}

DANIEL LINS

\begin{abstract}
RESUMO: Uma pedagogia rizomática, que tem como axioma primordial uma ciência nômade ou itinerante está inserida na ética e na estética da existência, na imanência, pois, como vida e emerge como pura resistência, puro devir. Eis um dos eixos do projeto de uma escola inserida numa dinâmica do rizoma: resistir, infectar e vitalizar o instituído. Numa pedagogia nômade os saberes tornam-se sabores porque permitem as inteligências aceder a um universo outro. Os saberes como sabores não mudam a realidade finita dos homens, mas atribuem ao "incompreensível" uma realidade artística, criadora.
\end{abstract}

Palavras-chave: Pedagogia. Rizoma. Molar. Molecular.

\section{MANGUE'S SCHOOL OR FOR A RIZOMATIC PEDAGOGY}

ABSTRACT: A rizomatic pedagogy whose main axiom is a nomadic or itinerant science and could act as a counterpoint to the royal science is embedded into the ethics and aesthetics of existence, into immanence. As life, thus. It rises out as pure resistance, as pure becoming. Here is one of the axes of a School following a rizomatic dynamic: resisting, contaminating, and vitalizing what has become established. In a nomadic pedagogy knowledge turns to be flavors because it allows intelligence to access another world. Knowledge as flavor does not change the finite reality of human beings, but attributes to the inexplicable an artistic and creative reality.

Key words: Pedagogy. Rhizome. Molar. Molecular.

Pós-doutor em filosofia (Université Paris VIII) e psicanalista; professor da Universidade Federal do Ceará (UFC).E-mail: dlins@secrel.com.br. 


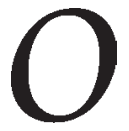

projeto de uma pedagogia rizomática, que tem como axioma primordial uma ciência nômade ou itinerante, contraponto aos delírios de uma ciência régia, "destinada a tomar o poder", está inserido na ética e na estética da existência, na imanência, pois, como vida. Uma tal pedagogia emerge como pura resistência, puro devir (Deleuze \& Guattari, 2002, p. 41).

Eis um dos eixos do projeto de uma escola inserida numa dinâmica do rizoma: resistir, infectar e vitalizar o instituído, no aqui e no agora da pedagogia "real", isto é, no molar em ruptura com o molecular, no molar não mais acoplado ao molecular como diferença, mas asfixiado pelo ideal identitário, para o qual o retorno é redundância vazia e não diferença.

Cabe, todavia, acrescentar outros aspectos importantes que inspiram uma possível pedagogia rizomática: o reconhecimento da criança como irredutível à visão de um adulto em miniatura e a afirmação de um presente da infancia, que é devir e não simplesmente uma preparação para a vida adulta, para um futuro longínquo: "Estude e terá uma boa profissão!"

Para Deleuze e Guattari, as crianças são acontecimentos. Devir, acontecimento, as crianças são dissidentes de um decalque traçado para elas, muitas vezes exterior aos seus desejos, o que as motiva a resistir a modelos pedagógicos, embora "legítimos", ancorados, contudo, na pedagogia voltada para o futuro, atrelada à tentação permanente que atravessa a história dos homens e assimila com obstinação parentesco e causalidade, sob o signo de uma ciência régia que se erige em supostos modelos estáveis.

Ao contrário, no contexto de uma pedagogia dos sentidos, pedagogia rizomática, nômade, os saberes tornam-se sabores porque permitem as inteligências, às crianças, aceder a um universo outro: ser bruxo com os bruxos, compartilhar da compreensão dos mistérios do nascimento, do amor, da vida, da morte, sem drama, sem histeria, sem dívida, mas com fantasia criativa acoplada à reflexão e não à indução. Os saberes como sabores não mudam a realidade finita dos homens e, tampouco, a angústia vinculada à morte. A realidade continua sendo o que ela é, mas o olhar que se tem sobre ela transforma não a força das coisas nos seus paradoxos e incertezas, mas atribui ao "incompreensível", sob o olhar ético e estético, para além do bem e do mal, uma realidade artística, criadora, isenta do imaginário divino, do juízo, da verdade, da punição e do castigo.

A descoberta, pois, pela criança das coisas da vida, mediante um aprendizado descolonizado, leigo, da complexidade do universo, de uma 
filosofia positiva e não niilista da morte, de um discurso criativo do desejo e do gozo, sob o signo das ciências, poesia e música, artes e amizade. Todo esse capital cultural, curado da culpa e do modelo adâmico de humanidade, desumanizaria não só os saberes teleguiados, grudados como uma ferida da língua na transcendência e no racional, mas inauguraria uma Gaia ciência, na esteira da qual o pretium doloris não seria mais uma dívida para com o Absoluto, porém um cuidado de si e dos outros. Outrem como acontecimento e não como condenação ou fatalidade.

Criar dispositivos alegres para passar realidades muitas vezes duras, segundo a possibilidade de cada criança, singularidade única, não repetitiva, encontra talvez na máxima criada por Édouard Claparède, para definir La Maison des Petits, em Genebra, o equilíbrio necessário à barragem às utopias delirantes: "La Maison des Petits é a escola na qual as crianças não fazem o que elas querem, mas querem o que fazem".

A ética dos afectos ${ }^{1}$ não é uma produção dos medos "místicos" nem "científicos", contudo o resultado de uma inteligência do sensível, sob a força de uma construção que passa pelos saberes-sabores sem negligenciar as intensidades neles veiculadas pelos intercessores, pelo bom encontro, isto é, pelo bem. É uma questão de estilo e de leitura:

Hoje dispomos de novas maneiras de ler, e talvez de escrever. Há maneiras ruins e sujas. Por exemplo, tem-se a impressão de que alguns livros são escritos para a resenha que um jornalista supostamente fará, de modo que ele não precisa sequer de resenha, mas apenas de palavras vazias (...) para evitar a leitura do livro e a confecção do artigo. A boa maneira para se ler hoje, porém, é a de conseguir tratar um livro como se escuta um disco, como se vê um filme ou um programa de televisão, como se recebe uma canção: qualquer tratamento do livro que reclamasse para ele um respeito especial, uma atenção de outro tipo, vem de outra época e condena definitivamente o livro. Não há questão alguma de dificuldade nem de compreensão: os conceitos são exatamente como sons, cores ou imagens, são intensidades que lhes convêm ou não, que passam ou não passam. Pop'filosofia, não há nada a compreender, nada a interpretar. (Deleuze \& Parnet, 1998, p. 12)

Como, todavia, contaminar a pedagogia da "realeza", da ciência, do pensamento que só pensa o que deve ser pensado? A "receita" do alegre caos de alguns segmentos do "Movimento Sem-Terra", malgrado suas contradiçôes e tentação molar, identitária, segmentaridade dualista; sua oscilação entre $\mathrm{molar} / \mathrm{molecular} / \mathrm{molecular} / \mathrm{molar}$ pode inspirar uma pe- 
dagogia rizomática inserida no movimento, abrindo à criação e às conexões: desterritorialização e linhas de fuga. Rizoma e não árvore. A árvore define o território, o crescimento vertical e a identidade do ser. O rizoma é horizontalidade que multiplica as relações e os intercâmbios que dele se originam. A vida assim compreendida é um contínuo fluxo e refluxo, potência de interação e produção de sentidos.

O molar é aqui compreendido não como separação ou oposição. De fato, se é verdade que o molar delimita os nós, os laços, a arborescência, o molecular une-os numa desunião criativa instauradora, inclusive, de possíveis alianças. Atravessado (molar) e atravessador (molecular) celebram núpcias com intensidades singulares e diferenciadas, num movimento permanente de contaminação, dissidência e resistência, sob o signo de linhas de fuga e agenciamentos maquínicos, que conduzem um futuro sem devir e estruturas arborescentes para devires múltiplos, multiplicadores.

Assim, a linha molar e as linhas de fuga não podem absolutamente ser exiladas ou paralisadas numa dualidade ou diferença sem diversidade, contudo, compreendidas como linhas de fuga inerentes à pedagogia dos sentidos, das artes, do rizoma e da imanência, mesmo porque a nomadização de pontos ou linhas de fuga não pode pertencer à ciência, ela é, antes, da alçada da arte, mas no sentido de uma perversão das totalidades.

Esta espécie de ateísmo do molar, na sua positividade invisível (possível intercessor e não apenas inércia), faz parte das técnicas nômades das feiticeiras: com a idéia de ocupação de espaço, onde não são nem esperadas nem desejadas, numa prática do modelo americano teaching in, o MST ocupa lugares do poder para dizer o indizível, criando problemas e não buscando soluções, mesmo se, não raro, fecha-se no molar, nas estruturas viciadas das palavras de ordem deslavadas por práticas sôfregas que impedem a eclosão do novo e provocam a crise em vez de engendrar devires. A idéia de "solucionar problemas", neste contexto, é quase sempre capitulação, arranjos, simulacros, intoxicação voluntária, o contrário, pois, da criação, da invenção.

Paralela à ciência nômade, emerge não só a receita da feiticeira, o caos como arte e imanência, mas a vassoura da feiticeira, rizomática e não arborescente, ponto de vida e não apenas ponto de vista, estilo de vida e não moda ou modismos. Se o estilo - de vida, de existência - é estético, 
sua força maior é ética, em oposição à moral. O estilo num professor, num educador, num matemático ou em um grande escritor:

(...) é sempre também um estilo de vida, de nenhum modo algo pessoal, mas a invenção de uma possibilidade de vida, de um modo de existência (...). São os estilos de vida, sempre implicados, que nos constituem de um jeito ou de outro. (Deleuze \& Parnet, 1998, p. 125-126)

A ciência nômade ou itinerante busca a nomadização dos pontos de fuga, ao contrário das "ciências exatas" cristalizadas na memória dos saberes, da Ciência do Rei ou da Filosofia do Estado, paralisadas na repetição e dissecação de verdades desidratadas. Mormente o diálogo com saberes pedagógicos, para além dos pontos de vista da abordagem normativa ou objetiva, insere-se numa política do desejo, o que implica auscultar o espaço político na sua polissemia infinita. Neste quesito, o perspectivismo de Nietzsche motiva-nos e instiga-nos, abrindo vias para discussões positivas, férteis. Do mesmo modo, o aforismo nietzscheano, que afirma ser a doença uma perspectiva superior da saúde, oferece também uma pista bastante sedutora, sobretudo se a palavra "perspectivismo" é compreendida no sentido geométrico do termo.

Sabemos que a reprodução, que num plano tem duas dimensões de um objeto qualquer em três dimensôes, supóe uma técnica dita de projeção, o que implica o recurso aos pontos de fuga. É em referência a este mecanismo que o enunciado nietzscheano toma todo o seu sentido: a doença é uma variação contínua que abre para um número incalculável de experiências e experimentos, e a idéia que se faz da saúde determina antes uma só perspectiva que nos apraz designá-la como a melhor. Isso leva a concluir - paráfrase de Nietzsche - que o paradoxo é uma perspectiva superior do sentido e da significação. A nomadização dos pontos de fuga é uma pedagogia de alta potência: pedagogia rizomática - pensar o impensável do pensamento, pensar o não-pensável do pensamento, pensar o pensamento na sua dimensão desejante, vitalista; o pensamento como vida e crueldade: Grausamkeit (Lins, 2001, p. 47-57).

A cartografia nietzscheana do pensamento faz, pois, intervir a função de proliferação do sentido - rizoma - no interior do espaço político. De fato, "a natureza problemática da distância entre aquilo que é e aquilo que deveria ser significa, precisamente, que há um excesso de sentido" (Daignault, 1985, p. 126 e 223). Essa proliferação de sentido 
provoca verdadeiramente a queda do platonismo. O marxismo e o existencialismo, principais artesões da dialética, cada um a sua maneira, pretendiam provocar essa queda, mas "a perversão - e aqui está o seu sentido pleno - não reconhece ao "todo" a propriedade do ser maior que a soma de suas partes; ela afirma, antes, que o "todo" não é senão uma soma infinita de partes. Do mesmo modo, praticar a proliferação do sentido no espaço tecnológico bloquearia a ciência e retiraria, in extremis, a própria possibilidade da linguagem; pois pensar o "todo" como uma soma infinita de partes corre o risco de confundir precisamente os níveis lógicos.

Ora, segundo a terminologia de Deleuze, apropriada de modo criativo por Daignault, marxismo e existencialismo pertencem de fato à subversão, isto é, à reversão dialética de Platão; mas a reversão real de Platão - aquilo que por analogia acreditamos ser a passagem do espaço tecnológico da educação para o espaço político - não consiste no desmoronamento dos valores postos no eixo vertical das Idéias e da Matéria, da Essência e da Existência - mas antes no eixo "horizontal" das superfícies, demarcado pelas verdadeiras e falsas cópias, ou pelos simulacros. Para Deleuze, a reversão do platonismo tem sua origem nos estóicos e a seguir em Nietzsche (Deleuze, 1998, p. 259-271).

\section{Pedagogia rizomática ou alteridade sem outrem}

Ao contrário da maioria de sistemas educativos, assentados na representação, a proposta que aqui se esboça não pretende repetir as pedagogias arborescentes, mas pensar, imaginar, engendrar, embora de modo sucinto, uma pedagogia dos possíveis, uma pedagogia rizomática, sem raízes, troncos, galhos ou folhas fundadores que dividem as coisas firmando a árvore como "ato inaugural" de todo processo educativo. O tronco sustenta e rege a hierarquia, sob o signo de uma ordem, segundo a qual todo desacorde é interpretado como dissonância, cacofonia, falta de harmonia. Tudo parte do tronco, este por sua vez se divide em galhos e em folhas, instalando a genealogia familiar e a redundância sem corpo, barreiras fincadas contra o retorno da diferença e do movimento autônomo das alianças não-edipianas. Ora, é justamente em oposição ao caráter hierárquico e asfixiante da árvore que o projeto rizomático emerge como possiveis ao possivel da educação. Um encontro nômade, pois, e não uma palavra de ordem. Um conversar com no lugar de um falar sobre. Trata-se 
de nutrir o bom encontro, aqui compreendido com o bem, marcado pelo desejo ético e estético de criação.

A criação, pois, como um ato ético, um afecto, um agenciamento vibrátil, conectado às caravanas do deserto, é um ato de amor sem demanda: nem falta nem luto, todavia desejo ao qual nada falta, sequer a falta da falta. Não é o desejo que é falta, mas o que falta é o desejo. A criação como barreira ao desejo niilista: carência e demanda abjeta de amor! O ser não é dado, mas querido, almejado, conquistado; neste sentido, o ser é autoprodução. Não se nasce ser, torna-se, ou não, ser. O ser não é uma questão de substância ou de transcendência, o ser é uma produção desejante: pura invenção do desejo. Eis por que "É preciso colocar o mundo no sujeito, a fim de que o sujeito seja para o mundo" (Deleuze, 2000, p. 51).

Trata-se, pois, da determinação de um-para o mundo em vez de serno mundo: "Vamos das inflexões do mundo à inclusão em sujeitos" (idem, ibid., p. 45); ou, como diz Plotino, "Multiplicamos a cidade sem que ela funde esta operação" (apud Deleuze, 2000, p. 43), isto é, o cuidado de si e o cuidado do outro. A inclusão passa pela invenção dos desacordos e criação das diferenças numa espécie de alteridade desejante, isto é, uma alteridade sem outrem estruturado e estruturador de ressentimentos e dívidas. De fato, a culpa alimenta sempre um poder simulado, às vezes ridículo, contudo terrivelmente real: eu, macho, em meu lugar, falando em nome das mulheres; eu, poder patrimonial, em meu lugar, falando sobre os "desvalidos"; eu, professor, em meu lugar, falando em nome dos alunos.

Poderíamos pensar uma ética sem alteridade, em que não se está condenado ao outro, o outro como meu pecado original (Sartre), mas que, ao contrário da moral niilista, não limita outrem ao "ser humano", ofuscando, assim, a grandeza de uma alteridade grávida de devires, isto é, sem reciprocidade imposta como sina ou destino, uma alteridade, pois, que passa pelos afectos, encontros com outrem eclodido, em platôs abertos e rizomáticos. Uma alteridade como uma invenção, um devir-criança, e não um dado. Penso numa ecologia do espirito: outrem como o conjunto da natureza, não limitado ao mais mortal dos seres, o homem adâmico, resultado da queda e do pecado, memória das chagas e da carne silenciada, ciliciada. Outrem, assim compreendido, supera o outropessoa-sujeito, o indivíduo, abrindo-se ao não-humano do homem, ao desumano, ao universo múltiplo, como um imenso sujeito eclodido: 
caosmos e devir aos mil afectos e desejos, inocência do devir, devir do pensamento trespassado por um eterno retorno, que "não faz retornar tudo", nem se deixa encurralar pela representação: "O segredo do eterno retorno é que não exprime de forma nenhuma uma ordem que se opõe ao caos e que o submete. Ao contrário, ele não é nada além do que o caos, potência de afirmar o caos (...). À coerência da representação, o eterno retorno substitui outra coisa, sua própria cao-errância” (Deleuze, 1988, p. 269-270).

Um outro, portanto, que reage: um outro em devir, um devir outro que resiste inclusive à recente fundação da infância, mesmo porque "o que deve ser fundado é sempre uma pretensão" (idem, ibid., p. 260). Cabe, pois, resistir à representação humanista da infância, objeto de fascinação programado, enclausurado num futuro longínquo separado do devir, em que a criança, ou o estudante, fabricado segundo as leis do mercado, perde a transversalidade do presente metamorfoseando-se num invólucro, uma criança como jogo regressivo dos adultos, uma caricatura da infância, que é, por definição, dissidente. Reconhecer a infância, afirmar seu presente é aceitar, como diz Meirieu, sua existência: ora, se a criança existe, a criança resiste (Meirieu, 1996).

Rizoma e pedagogia do desastre

A pedagogia do desastre: falar pelo outro, pensar para o outro, fabricar a criança, o aluno insere-se na tentação conservadora, mais próxima do estudo dos monstros que da pedagogia. Fabricar uma criança equivale a ofuscar a própria criança. Mata-se no ovo (Corpo sem órgãos?, Lins, 2004a) a emergência de uma metafísica sem Deus - metafísica da carne - aliada à produção de aprendizados, de descobertas nômades de corpos erotizados e encontros com saberes vibráteis, saberes-pele, poros e sonhos molhados. Vitalidade, pois, sem culpa nem referência adâmica, domadora de desejos rebeldes, de vida.

Não, eu não matei o Cristo. Não, não sou assassino antes de ter cometido meu crime, diz o primitivo na sua inocência ativa, permeada pela ética da crueldade e dos sentidos. Um primitivo é o antípoda de Emílio, de Rousseau, herói pedagógico, fundado segundo as prescrições de uma natureza por definição boa, engendradora de uma utopia pedagógica que perde o sentido do lugar-não, extasiando-se numa idealização próxima de um terrorismo niilista daqueles que carregam uma árvore na cabeça. 
Desenho pedagógico, rico em boas intençôes e infinita generosidade, a pedagogia do desastre está encurralada num dever-ser, numa memória do não-esquecimento, atravessada por uma perspectiva normativa em que as ervas do rizoma, a grama, cedem lugar às raízes, às estruturas enfermas, às doces prisōes sem grades. Ora, segundo Deleuze, “(...) há duas grandes doenças da estrutura: o preenchimento da casa vazia por seu sujeito de acompanhamento e o abandono da casa vazia pelo sujeito do acompanhamento; em suma, terrorismo e niilismo na educação" (2000, p. 50).

Por que afirmar que há no preenchimento da casa vazia, em Rousseau, um efeito de uma pedagogia terrorista? Podemos dizer, em forma de esboço, que há em Emílio uma espécie de eco a esse lugar - casa vazia - sem ocupante. Rousseau, sabemos, tenta construir uma educação em conformidade com as leis da natureza. Destarte, ele força as condiçóes objetivas a fim de realizar seres como Emílio e, simultaneamente, criar uma sociedade à imagem do paraíso terrestre. Georges Lapassade, em 1956, e Jacques Daignault, em 1985, apresentaram estudos rigorosos e críticos a este respeito. Cabe aqui, na esteira desses pensadores, sublinhar dois aspectos da questão:

Se é exato que apresentar a imagem de uma sociedade como paraíso terrestre constitui uma violência, semelhante "a condicionamentos 'operantes' e a ditaduras mórbidas", e que “é, no fundo, o que se pratica, em graus diversos, mormente, ali onde se procura realizar os maiores ideais pedagógicos" (Daignault, 1985, p. 123-132) não se pode cair no erro contrário que consiste em recusar definir um ideal, e logo deixar a casa vazia escavar realmente uma lacuna que seria cedo ou tarde vivida como uma falta, um excesso (mais-valia de representação, ideal arborescente).

Creio, todavia, que há no próprio Rousseau uma terceira margem - praticada por ele com cuidado - para pensar uma pedagogia vinculada à natureza, numa perspectiva artística, com tudo o que isso implica como engajamento político, intensidade poética e sensibilidade nômade. Essa terceira margem, sumamente importante, sinaliza o fracasso das abordagens normativa e objetiva. São os perigos de querer ocupar ou reduzir a distância entre o normativo e o objetivo que incitam, paradoxalmente, à prudência do excesso artístico. Sabemos que os dois grandes acidentes da estrutura são, de um lado, o preenchimento da casa vazia e, por outro, seu abandono a sua própria sorte: "Esses dois excessos traduzem muito bem, acreditamos, as tendências atuais da educação. Isso tem como efei- 
to excluir tanto o estrito prático do campo científico como o teórico do campo educativo" (idem, ibid.).

No primeiro caso, tem-se um terrorismo, pelo menos de duas maneiras: antes de tudo, toda transformação radical daquilo que é, segundo o que se acredita que deve ser, implica uma violência contra o real, sempre movediço, sempre por vir. Quando essa violência, todavia, tem como real, precisamente, a criança, não é exagero falarmos simplesmente de terrorismo pedagógico. Isso acontece em sistemas "democráticos", não se precisa mais de ditadura para este tipo de economia pedagógica do terror (Lapassade, 1956; Deleuze, 1962b; Meirieu \& Develay, 1992).

Outro aspecto importante da debandada contemporânea, com relação à educação, é o acúmulo de doutrinas educacionais geradas pelo mesmo ventre, com suas pequenas diferenças, mas carimbadas por uma espécie de pensamento único, globalizado, improvisado, à velocidade do virtual, mas sem virtualidade. Concorrentes, sob o mesmo plano ideológico, cada segmento tenta convencer os outros - sobretudo, o Estado, a Educação Oficial - de que sua doutrina é a melhor. Esta situação está próximo daquilo que Lyotard chamou de um terrorismo teórico cujos efeitos, em longo termo, incitam irremediavelmente ao terror:

Chegou a hora de interromper o terror teórico (...). O desejo do verdadeiro, que alimenta em todos o terrorismo, está inscrito em nosso uso o mais incontrolável da linguagem, de modo que todo discurso parece desenvolver naturalmente sua pretensão a dizer a verdade, por uma espécie de vulgaridade irremediável. Ora, chegou o momento de medicar essa vulgaridade, introduzir no discurso ideológico ou filosófico o mesmo refinamento, a mesma força e leveza presentes nas obras de pintura, de música, de cinema, dito experimental, como também nas ciências. Não se trata em absoluto de inventar uma ou teorias novas, menos ainda de interpretações; o que nos falta é uma diabrura (...) de tal modo que o próprio gênero teórico seja objeto de subversões das quais sua pretensão não se levante mais; que volte a ser simplesmente um gênero e seja relegado da posição de controle ou dominação que ocupa, no mínimo, desde Platão; que o verdadeiro devenha uma questão de estilo. (Lyotard, 1997, p. 9-10)

\section{Devir-pedagógico e sentidos bárbaros}

Cabe, pois, cultivar, como experimentos e não como normas ou modelos, os sentidos bárbaros não ainda domesticados, e não apenas as 
significações ou os significados ordenados - aquilo que é, a saber, uma série significada, e aquilo que deveria ser, isto é, uma série significante , pensados de antemão, triturados e servidos como potinhos requentados às crianças e aos alunos, quase sempre alheios, porque criativos, a todo processo pedagógico ancorado no triângulo do desejo niilista: $p a-$ pai-mamãe-bebê!

Experimentar, mas nunca oficializar (uma minoria, uma vez oficializada, torna-se uma maioria) ou impor, como modelo esta ou aquela pedagogia, porém contaminar os processos pedagógicos com "costumes bárbaros". Se a ideologia utilitária mapeia o dia-a-dia de cada um, tudo grava, cataloga, por que a educação seria diferente? Como pensar a produção do inútil nas escolas? Reuniões "inúteis", "sem agenda", encontros "inúteis", oficinas "inúteis", tudo isso são experimentos e "práticas bárbaras" no campo dos afectos não estruturados nem estruturáveis ou oficializados, conseqüentemente não fadados à repetição, ou ao tédio da experiência cooptada pela norma, pelo imaginário instituído. Tudo isso educa para o sensível, para se pensar fora do pensamento único. Tudo isso significa não um método, mas um pouco de ar fresco, uma diferença mínima, um afecto minimamente não-controlável, uma onda de alegria na arte de aprender e de coabitar.

Nem retorno triste ao passado, nem apologia da nostalgia, nem conselhos, o que nos move são os conceitos, personagens, colados à vida, como a respiração. Silêncio, olhar do silêncio, diálogo, narrativa, espaços nômades de vida inseridos à escola. Ao reverso de oraçóes ou rezas, cabe propagar encontros, espaços para nada, 10 minutos, 20 minutos de contágio com os devires encarnados, velados, em cada aluno. Devir-poeta, devir-animal, devir-mulher, devir-carrapato, devir-criança, devir-aprendiz. Convém observar que há no devir-pedagógico um movimento de pura arte, pura criação. Não se trata de fazer igual, copiar, imitar. "Devir nunca é imitar", diz Deleuze. Aqui há problema, logo, matéria a ser pensada. O devir é também da ordem do paradoxo: não se pode prever, nem calcular; o devir é imprevisível, é o não-prescrito. A lógica linear cede lugar ao acontecimento. O devir-outro passa por uma ética da alteridade sem "garantia" de reciprocidade, nem semelhança, nem "amai-vos uns aos outros como eu vos amei”, pois amar todo mundo é não amar ninguém: o mesmo no mesmo é da ordem da imitação. Eis a questão - etimologicamente, o substantivo "questão" significa tortura -: a imitação, na esfera do devir, anuncia o fracasso do próprio devir: 
A vespa e a orquídea são o exemplo. A orquídea parece formar uma imagem de vespa, mas, na verdade, há um devir-vespa da orquídea, um devir-orquídea da vespa, uma dupla captura, pois "o que" cada um se torna não muda menos do que "aquele" que se torna. A vespa torna-se parte do aparelho reprodutor da orquídea, ao mesmo tempo em que a orquídea se torna órgão sexual para a vespa. Único e mesmo devir, único bloco de devir, ou, como diz Rémy Chauvin, uma "evolução a-paralela de dois seres que não têm absolutamente nada a ver um com o outro". Há devires-animais do homem que não consistem em imitar o cachorro ou o gato, já que o animal e o homem só se encontram no percurso de uma desterritorialização comum, mas dessimétrica. (Deleuze \& Parnet, 1998, p. 10-11)

Uma Escola do Devir é cercada por caravanas móveis e não por estruturas fixas, de concreto armado; ela é geografia e não história. Sensível, à escuta de intercessores de uma pedagogia outra, sem compromisso definido com o sucesso a qualquer preço, a pedagogia rizomática abre espaços para uma pedagogia do acontecimento e das trocas simbólicas acoplada a uma estética do "inútil”, rica em produção rizomática, em devires, tão cara aos ameríndios bororo, mestres do esquecimento ativo (Lins, 2004b).

Pensar uma "metodologia" do acontecimento é optar por uma gestão do tempo pedagógico, para além da cronologia e da lei, ou daquilo que é suposto ser a lei, sem, todavia, negar a importância dos limites compartilhados e não impostos. Um espaço de vida, no âmbito da escola, é uma espécie de não-lugar pedagógico onde os devires imperceptíveis podem, como os nômades do deserto, encontrar-se, não numa estrutura, mas numa confidência, numa sedução, numa invenção artística. $\mathrm{O}$ tempo de ócio produtivo deveria também ser um tempo escolar. Raro e, em geral negligenciado, ignorado ou criticado, esse tempo, praticamente ausente das escolas, tem seu charme, seu estilo (Deleuze \& Parnet, 1998, p. 14) e sua grandeza: leveza, sedução, sonhos e encontros múltiplos que superam a fixação pessoal (sujeito humano, indivíduo), apontando como uma flecha para os encontros-devires, sem humanidade nem animalidade definidas, chapadas, revelando-se no outro, que é cosmologia, e na cosmologia, que é outro, numa linha rizomática sem simbiose nem cópia:

Um encontro é talvez a mesma coisa que um devir ou núpcias (...). Encontram-se pessoas (...), mas também movimentos, idéias, acontecimentos, entidades. Todas essas coisas têm nomes próprios, mas o nome próprio não designa de modo algum uma pessoa ou um sujeito. Ele designa 
um efeito, um ziguezague, algo que passa ou que se não passa entre dois sob uma diferença potencial: (...) "efeito Kelvin". Dizíamos a mesma coisa para os devires: não é um termo que se torna outro, mas cada um encontra o outro, único devir que não é comum aos dois, já que eles não têm nada a ver um com o outro, mas está entre os dois, que têm sua própria direção, um bloco de devir, uma evolução a-paralela (...), núpcias, sempre "fora" e "entre". (Deleuze \& Parnet, 1998, p. 14-15)

Potência de interação e produção de sentidos, a arte na educação nutre-se do contágio que o vínculo pedagógico provoca, na expansão de cada vida que, como a orquídea e a vespa, deixa-se contagiar pelo desejo.

Trata-se, pois, de escapar à alteridade-enfermeira, espécie de ideal de santidade em que o agente - aquele que age e não é agido, próprio ao devir-criança do pensamento - deve se esvaziar de si mesmo, de seu desejo e vontade de potência positiva, e ceder lugar ao "ser humano", num humanismo acordado pelo diapasão da primazia da moral sobre o material, do coletivo sobre a singularidade, do niilismo sobre o por vir: uma ética-enfermeira que sufoca a vontade criativa e ofusca a infância em devir.

Ora, uma ética-enfermeira, ancorada por excelência na moral dos fracos, cultiva o tronco, instiga a pedagogia da árvore: cada criança é encorajada a ter uma árvore fincada na cabeça e, para que não esqueça a genealogia, professoras insistem, ainda, em serem personagem sem nome, pura arborescência: a Tia! Persona. Máscara da máscara.

\section{Mangue's School}

- Seu Pedro, onde começa o mangue?

- Professor! Olhe o mangue! Não tem nem começo, nem fim: o mangue só tem meio!

(Diálogo com um velho pescador, na Ilha do Pinto, em Fortim, Ceará, abril de 2004)

A árvore, lugar primordial da hierarquia, do nome próprio, do brasão e da genealogia familiar, estabelece tudo de antemão. É o sistema classificatório no seu apogeu. Classificação que começa no ventre materno: nota-se tudo, escreve-se tudo, tudo é digitado, mapeado. Eis por que a pedagogia arborescente, deflação de estrutura, tem seu alto e seu baixo, seu começo e seu fim. O contrário, pois, do rizoma que é meio, intermezzo, inter-ser, que não tem alto nem baixo, nem começo nem fim: um 
ponto do rizoma é conectado a todos os outros pontos, fazendo da escola um imenso manguezal que se espraia num entrelaçamento de proteínas, calorias, gazes, lama, gozos, prazeres, detritos e... ouro (o caranguejo, em particular, e os crustáceos, em geral, são o ouro dos mangues), esquecimento ativo e devires, sem simbiose nem filiação, mas alianças, intercessões, vizinhanças.

Faz-se mister olhar o mangue como se olha o meio: um olhar de índio. Olhar que não vê por antecipação, mas que deixa eclodir o novo, sob a força duma ética (e estética) do olhar: sem lodo nem aviltamento, numa repetição sem semelhança, mas como diferenciação, numa contemplação vibrátil, sem determinação, mergulhada numa visão que inventa a visão do que é visto sem pontos de referência nem muletas. O que eu vejo é ainda o que verei a partir da invenção e não da representação; mas o olhar que acolhe o mangue é um olhar órfão: nem começo nem fim. E a visão supõe a produção que, no mangue, passa necessariamente pelo inter-ser, inter-olhar, sob o signo de uma individuação que é pura fulguração no curso do tempo. Eis, pois, um possível esboço de uma pedagogia rizomática: Mangue's school.

Pode-se afirmar que a criança é uma obra em construção e que a escola é seu intercessor privilegiado na autoconstrução? Talvez. À condição, porém, que a transmissão de saber não se torne uma transmissão de poder, uma palavra de ordem a qual o aluno é suposto querer ouvir, aceitar e obedecer:

Uma lógica de transmissão do saber é ao mesmo tempo a transmissão de uma ordem; e uma lógica onde o ato de aprender é primeiro um ato. O saber não se transporta de uma cabeça para outra. Existe algo que se passa em uma cabeça, e alguma coisa que se passa em outra. $\mathrm{O}$ saber não se transporta nunca. Ele busca uma continuidade entre as formas do aprendizado habitual aprende-se olhando, adivinhando, comparando etc. - e as formas supostas metodológicas da transmissão de saber. (Rancière, 2004, s/p.)

Deleuze, por sua vez, afirma:

A escola parece ainda não saber furar, limar o muro. As escolas gostam demais das raízes, das árvores, do cadastro, dos pontos de arborescência, das propriedades. Vejam o que é o estruturalismo: é um sistema de pontos e de posiçóes, que opera por grandes cortes ditos significantes, ao invés de proceder por crescimentos e estalos, e colmata as linhas de fuga, ao invés de segui-las, traçá-las, prolongá-las em um campo social. (Deleuze \& Parnet, 1998, p. 50) 
Os ensinamentos e aprendizados que compóem a criança, não sendo destinados a permanecer para sempre no seu corpo e afectos, desagregam-se progressivamente ao longo do tempo e da emergente constelação de novas imagens, do novo. A dinâmica rizomática, acoplada ao esquecimento ativo e à memória das palavras (Lins, 2000), atenua os estragos da memória das marcas (arborescentes) e do ressentimento, e a fúria nãocriativa das lembranças cristalizadas em culpas e dívidas. Ora, o novo é o que está por vir, para que ele seja, é preciso que haja o esquecimento, uma memória das palavras, aquilo que não é ainda, e que, desde que passa a ser, torna-se memória, passado. A pedagogia rizomática, neste sentido, trabalha sempre com o novo. Eis, pois, toda a sua dinâmica: o que é (a memória) dá lugar ao que não é ainda (o novo, que implica o esquecimento). O novo é o devir, é o por vir. Nem genealogia, nem raízes: rizoma, abertura para a imanência, num eterno retorno em que o que retorna são os blocos de diferença em forma de devires. É o próprio real que aparece como produção do novo, o que supõe uma passagem do agente - itinerante, por definição - por uma experiência singular. O novo, cuja força maior é seu caráter primitivo ou imediato da novidade, ora posto pela experiência, ora pelo ser, não significa que ele se apresente espontaneamente nem que seja reconhecido imediatamente como tal pelo pensamento, mesmo porque o pensamento, muitas vezes dependente da opinião, é impotente para acolher o novo.

Mormente, o que caracteriza o novo em Deleuze é o fato de que o pensamento começa pela ruptura com a opinião. Neste sentido, Deleuze analisa a "imagem do pensamento" como um dispositivo de poder domesticado no pensamento para consagrar os valores estabelecidos, e reclama para a filosofia a criação de "valores novos".

É, de fato, o ser vivo, ou todo ser vivo, que produz ele mesmo sua existência por meio duma atividade criadora de soluçôes a cada vez inventadas em circunstâncias singulares. A vida impóe, pois, conceber conceitos capazes de dar conta duma atividade de criação. Neste sentido, Deleuze pensa a vida como princípio da novidade e da diferença, isto é, como novidade, como movimento de diferenciação que não pode ser pensado sem a vida, diferença, antes de tudo, como "diferença vital".

Por meio da questão do novo, a função da Mangue's School não é mais a de responder a uma necessidade de verdade, ou de abrir ao conhecimento do real, mas provocar "novas possibilidades de vida". O novo é assim retomado como uma exigência de criação que instiga a 
promoção de forças capazes de transformar o presente levando-o para novas vias, segundo a formulação de Nietzsche: "Agir contra o passado, e desse modo sobre o presente, em favor (espero) de um tempo por vir" (Deleuze, 1962a, p. 122).

Desde que o pensamento - na educação, ou alhures - tem como objeto o novo, torna-se experimentação. Ora, se para Deleuze o pensamento se define pela experimentação, cabe à filosofia da educação compreender a produção do novo no interior dos conceitos, ao passo que a arte, que é uma forma de pensamento, perceberá a novidade tão-somente por meio dos perceptos que inventa.

Em contrapartida, sabemos que o mundo imagético, o "banco de dados", renova-se não como uma máquina programada, mas como uma memória em devir que, ao elaborar o esquecimento das imagens/lembranças/recordações, cria simultaneamente outras imagens, outras memórias, num movimento que é renovação, involução, numa experiência virtual, isto é, mais real que o real.

Assim, a imagem do rizoma, descrita por Deleuze e Guattari, a imagem geral é a soma de todas as outras: e... e... e... sem que haja hierarquia nas imagens que a compõem. O limite do rizoma é fugitivo:

Oposto à árvore, o rizoma não é objeto de reprodução: nem reprodução externa como árvore-imagem, nem reprodução interna como a estrutura-árvore. $\mathrm{O}$ rizoma é uma antigenealogia. É uma memória curta ou uma antimemória. $\mathrm{O}$ rizoma procede por variação, expansão, conquista, captura, picada. Oposto ao grafismo, ao desenho ou à fotografia, oposto aos decalques, o rizoma refere-se a um mapa que deve ser produzido, construído, sempre desmontável, conectável, reversível, modificável, com múltiplas entradas e saídas, com suas linhas de fuga. (Deleuze \& Guattari, 2000, p. 32-33)

Deleuze compara a memória curta ao rizoma, e a memória longa à arborescência. A pedagogia rizomática apresenta semelhanças com o nosso cérebro e sua composição é feita de neurônios conectados entre eles por sistemas: "O pensamento não é arborescente e o cérebro não é uma matéria enraizada nem ramificada. (...) Muitas pessoas têm uma árvore plantada na cabeça, mas o próprio cérebro é muito mais uma erva do que uma árvore” (Deleuze \& Guattari, 2000, p. 25).

Uma pedagogia rizomática assemelha-se, ao mesmo tempo, a um prolongamento de nosso cérebro, a um desenvolvimento eclodido de nossa consciência, a uma consciência fluida que se estende em todas as 
direções, ou em nenhuma, embaralhando os códigos unitários e a linearidade que empobrecem a imaginação e afugentam os devires. Consciência, pois, que se nutre de outras consciências produtoras de devires inconscientes, engendrando uma desterritorialização e abrindose ao novo, ao impensável do pensamento, num espaço de criação em que os alunos se tornam os próprios rizomas.

Se o rizoma não tem efetivamente região, território ou lugar, é em razão de sua geografia, de suas ilhas e manguezal flutuantes; em outras palavras, é porque seus limiares são sensivelmente indistintos: nem zonas fronteiriças nem limites a serem apontados, consignados. $\mathrm{O}$ rizoma passeia num movimento constante de entrada e de saída negligenciando as circunscrições. Deste cao-errante, emergem as primaveras de uma pedagogia rizomática, nômade. Nada que rompa ou aparta, nenhuma superfície de separação, unicamente superfícies eretas ou espaços de ligações. Nem fronteiras, nem demarcações, nem orlas, uma expansão sem confins, nada que o enclausure, mas aberturas, espaços abertos, e, conseqüentemente, nem borda, nem começo, nem fim: sempre meio, pois, na pedagogia rizomática, coabitam microzonas, microssetores, rizomas correspondentes a cada singularidade. $\mathrm{O}$ rizoma é algo que se mostra: o oposto, pois, de uma pedagogia solitária que cultiva os "segredinhos!".

A desterritorialização é o monte inverso e a margem oposta da localização (para conservar um campo lexical oriundo do fluxo). Uma pedagogia nômade subtrai-se a toda e qualquer localização temporal e espacial, escorrega entre os dedos, não reside em um lugar nem em um ponto, contudo numa multiplicidade de lugares e pontos quebrantando toda determinação arborescente. Localizar é definir, nomear, logo da ordem do instituído. Do instituído ao institucionalizado é um passo: a geografia devém história, estrutura, genealogia, muralha contra a diversidade, educastração e não educação.

Destarte, a desterritorialização encontra sua força nas saídas: o território "dos animais dos territórios" não vale senão com relação a um movimento pelo qual dele se sai. Para Deleuze, não há território sem um vetor de saída do território, e não há saida do território (isto é, desterritorialização) sem que haja, ao mesmo tempo, um esforço para se reterritorializar alhures, em outra coisa (Deleuze \& Guattari, 2000, p. 11-37).

Tudo acontece por desterritorialização/territorialização, tudo opera, como nos sites, os espaços de mostração, de presentação do visual. Há 
deformação, mudança de estrutura, partida para outras estradas, novas peles, sempre para as mutaçôes, para o por vir. É o devir-criança inserido no coração do rizoma, o contrário, pois, da árvore: as estruturas arborescentes têm saudades do passado, são atraídas pelo cemitério, pelo pensamento-túmulo; o rizoma sente saudade do futuro, ele é a linha-artista por excelência.

Fica a pergunta: Como se propagar e se reterritorializar neste nãolugar, "plano de consistência", e "agenciamento"? Convém investir as singularidades em um campo lavrado pelas heterogeneidades, um lugar que é não-lugar, logo, deliberadamente, saída de todo lugar, um lugar sem lugar, e que não sofre por isso, ganhando em troca uma pluralidade indefinida de lugares, eis o que nos titila. O rizoma, como a internet, é a coisa conectada a qualquer instante, em qualquer lugar, em todas as línguas, segundo a criatividade de uma gramática das invençōes: política primordial da pedagogia rizomática, mas também a sua força nômade.

Uma oficina rizomática assemelha-se a um ateliê clássico: um espaço onde crianças, alunos, estudiosos, artistas, pesquisadores realizam seus trabalhos e dividem suas experiências. Se a oficina comum é fixa, e segundo sua definição, visível no espaço, a oficina potencial, no quadro de uma pedagogia nômade, instaura-se no relativo e no flutuante, ela troca sua forma e seu território por outras formas e territórios, segundo seu bel-prazer, embora com extremo rigor e conhecimentos intelectual e afetivo, sem os quais nenhum experimento é possível.

A pedagogia dos afectos alegres em detrimento da tristeza das certezas; a abertura às incertezas em detrimento da verdade ou da vontade arborescentes que asfixiam o desejo e exilam o aprendiz na memória dos traços, na ferida da língua e do corpo, tornando-o refém duma memória desidratada, do não-esquecimento passivo, niilista. Marcado pelo mimetismo sôfrego, pela cópia, pela ilusão duma centralidade, duma unidade que garante a "resolução", mas que impede toda criação de problemas, o romance edipiano é tristeza arborescente: "A árvore ou a raiz inspiram uma triste imagem do pensamento que não pára de imitar o múltiplo a partir de uma unidade superior, de centro ou de segmento" (Deleuze \& Guattari, 2000, p. 26).

O problema é aquilo a partir do qual a filosofia deve necessariamente pensar. $\mathrm{O}$ pensamento não tem como fundamento a busca da verdade - como se a verdade estivesse sempre disponível, à toa, esperando a 
nossa boa vontade para se manifestar. $\mathrm{O}$ pensamento está voltado não para o "estudo" de problemas, mas para a criação de conceitos. O problema não é uma questão, pois a questão supõe, de imediato, a resposta. A questão ou a interrogação sustenta-se na realidade vazia, o problema está alhures.

Lá onde se busca um centro, um começo, um fim, emerge como uma força bailarina o desejo de aprender, de crescer, de voar, afetado por uma pedagogia dos platôs - "Um platô está sempre no meio, nem início nem fim. Um rizoma é feito de platôs (...). Chamamos 'platô' toda multiplicidade conectável com outras hastes subterrâneas superficiais de maneira que formem e estendam um rizoma" (Deleuze \& Guattari, 2000, p. 33) - que apela para a criação de sentidos, superando toda e qualquer alteridade paralisada em outrem, no "ser humano", no General onipresente, ferrenho inimigo do corpo e dos afectos, do erotismo e das delícias compartilhadas da pele e das paixóes alegres, barreiras vitalistas contra o fechamento do rizoma e a instauração da reprodução em detrimento da produção e da expansão:

Contra os sistemas centrados (e mesmo policentrados), de comunicação hierárquica e ligações preestabelecidas, o rizoma é um sistema a-centrado não-hierárquico e não-significante, sem General, sem memória organizadora ou autômato central, unicamente definido por uma circulação de estados. O que está em questão no rizoma é uma relação com a sexualidade, mas também com o animal, com o vegetal, com o mundo, com a política, com o livro, com as coisas da natureza e do artifício, relação totalmente diferente da relação arborescente: todo tipo de "devires". (Deleuze \& Guattari, 2000)

A criança não sendo uma "floresta virgem", um mundo a "descobrir", ou um ser sem existência própria, o inexistente ("descobrir" uma criança é reproduzir a própria criança, segundo o estado de representação do colonizado, sob a imposição do eu, ficção colonizadora), mas um devir-manguezal, uma igualdade na desigualdade, dobras e desdobras, com as quais se pode ou não coabitar. Como o mestre, mutatis mutandis, a criança vive o dilema da igualdade não-mensurável, mas conceitual. Professor e aluno, ambos são dotados de saberes, experimentos, vivências, logo não são folhas brancas: cada um, a sua maneira, tem seu capital cultural, e isso desde a mais tenra infância. Neste quesito, há uma igualdade não-estatutária, não contabilizada nem competitiva, mas real: não há 
matas virgens, ambos possuem conhecimentos não-comparativos. $\mathrm{O}$ fato de que um e outro, contudo, tenham um capital cultural, emocional ou lingüístico aproxima-os duma multiplicidade rizomática, não gramatical nem hierárquica. O professor, suposto saber "mais" que a criança, não é superior ao aluno, suposto saber "menos" que o mestre, mesmo porque na "contabilidade" rizomática não há sinais negativos. Estamos, pois, no universo dos intercessores e não do General, dos devires e não das estruturas arborescentes. Saber ou não saber são devires imperceptíveis, sua percepção exige que se tenha pequenas orelhas, pequenos olhos, e ausência de hierarquias terroristas, interpretações assassinas, verdade ou juízo.

Como ficaria, neste contexto, o aprendizado? Que tipo de leitura conduz ao saber-sabor? Como fica a relação entre pedagogia, aprendizado, escola, rizoma ou imanência? Deleuze escolhe Dickens como intercessor para a definição de imanência. Já em Kafka: por uma literatura menor (Deleuze \& Guattari, 1977; cf. Lins, 2004c), a imanência é ao mesmo tempo princípio de escrita em Kafka e de leitura em Deleuze e Guattari. A imanência é a imanência da lei; a justiça atravessada pelo desejo, no Processo de Kafka; mas a imanência é também aquela da leitura sempre no âmago do texto, que procura perceber como ele funciona (o agenciamento). Falaremos neste caso de um aprendizado imanente, de um "método" rizomático que acolhe o ser zero ${ }^{2}$ da pedagogia que é, ao mesmo tempo, causa e dom, é o que não é ainda. O participado (suposto professor) torna-se o princípio ativo ao passo que o participante (suposto aluno) é o efeito. Sem hierarquia nem lugares, inauguram-se encontros e não apenas quadros relacionais. Professor e aluno, ambos intercessores, tornam possível aquilo que parecia impossível: transmitir sem dominar, transmitir sem ofuscar os devires, receber sem dever, sem morrer às criatividades nem se deixar engolfar por uma alteridade moral que esvazia, mediante a dívida e a erosão dos desejos, a vontade positiva de potência, vontade superior de desejar.

Em vez de engolfar o ser do sensível, o ser zero alicerça experimentos e experiências, reinventando um sujeito não sujeitado, não mais refém de uma identidade nem estruturado numa determinação que tudo "resolve", sem se importar com os devires. Ora, o desprezo pelo devir, ser zero por excelência, cristaliza o indivíduo num tecido letal, alheio à experiência, separado da vida, da imanência. Ao afirmar que o ser zero é por definição o devir, almejamos, sobretudo, realçar com Deleuze que o 
“devir não é ser” (Deleuze \& Guattari, 1997, p. 87; Simondon, 2003), o devir não é substância. Abre-se, pois, todo um universo à invenção pedagógica, ao engendramento de uma a-pedagogia em que a criança, o aluno, é uma entidade em devir, é o ser zero curado do dogma do ser, como representação, que deve ser administrado, catalogado, "formado", segundo as regras e rédeas de um pensamento que só pensa o que deve ser pensado, atrelado a uma pedagogia do rebanho.

Ser zero, ${ }^{2}$ o impensável, pensar o que não pode ser pensado e, contudo, deve ser pensado, é o involuntário: pensar como a criança que produz um pensamento sem pensamento. Esse ser zero restitui cada realidade singular na superfície do plano de imanência e tece um laço com o impensado, grau zero do ser - plano de imanência -, cada um dos termos permitindo um acesso ao virtual que aponta para a atualização das singularidades. O devir-pensamento assemelha-se ao devir-criança-dopensamento: pensar sem pensamento, pensar, pois, para além da noção de cultura freudiana, ou das amarras platônicas.

Pensar o impensável, pensar-com-o-corpo: o corpo toma então sua significação ontológica - Corpo sem Órgãos - quando ele abre a esta dimensão velada e impossível da experiência, quando ele abre ao tocável no seu próprio intocável, ao visível em seu próprio invisível, à consciência em sua própria inconsciência, ao Corpo sem Órgãos, propõe uma experimentação do limite de nosso ser, e força a reflexão a exprimir o inexprimível. Assim, Deleuze concluía com estas palavras uma conferência sobre a música:

Não há orelha absoluta, o problema é de ter uma orelha impossível - tornar audíveis forças que não são audíveis nelas mesmas. Em filosofia, trata-se de um pensamento impossível, isto é, tornar pensável, por meio de um material de pensamento muito complexo, forças que não são pensáveis. (Deleuze, 1978, s/p.)

Pensar é sempre seguir a linha do vôo da bruxa, é despositivar às instituições, percorrer infinitamente a experiência humana em busca de uma superfície de contato na qual se trama e se enreda o pensamento no impensado.

Reler sem cessar $o$ arquivo das palavras, revolver a representação, deixar que o pensamento ecloda na sua intensidade e no seu furor, escapando assim ao pensamento que pensa para nada: pensamento organizador de acoplamentos mórbidos, sob o selo de uma bondade ecumênica, aglutina- 
dora de uma economia perversa marcada por uma submissão incondicional ao fraco - eis o axioma primordial de uma pedagogia rizomática.

Poderíamos, pois, dizer que o pensamento-rizoma se produz no encontro heterogêneo com o sensível e não no elemento do pensamento (recogniçãa). "O objeto do encontro, ao contrário, faz nascer a sensibilidade do sentido" (Deleuze, 1988, p. 231), e o que é dado é um ser sensível, não o divórcio entre uma matéria amorfa e uma forma vazia, mas um signo:

Não é ser sensível, mas o ser do sensível. Não é o dado, mas aquilo pelo qual o dado é dado. Ele é também, de certo modo, o insensível (...) aquilo que só pode ser sentido (sentiendum ou ser do sensível) sensibiliza a alma, torna-a "perplexa", isto é, força-a a colocar um problema, como se o objeto do encontro, o signo, fosse portador de problema - como se ele suscitasse problema. (Idem, ibid., p. 231-232)

Em síntese, se é pela experiência que descobrimos que somos eternos, essa experiência não é sensível, mas fundamentalmente transcendental. Ela não é empirismo simples, todavia empirismo transcendental. A existência é uma experiência que nos permite pertencer à vida, à imanência, auscultando o sopro-movimento profundo da expressão. Cabe notar que há em Deleuze, inúmeras vezes, esta contigüidade, a "sublime confusão entre pensamento e Vida”, como se a Vida fosse tão-somente pensamento, soberano e imanente a todas as formas daquilo que vive. Vida e pensamento ultrapassam o sujeito que os recolhe. A Vida não é imanente a uma coisa, mas cria a imanência com a qual toda coisa se relaciona. Mas, se o ser é vida, desejo, imanência, o que é uma vida? A imanência como uma vida é Riderhood, em Our mutual friend, o "mau sujeito" de Dickens (Dickens, 1989, p. 443), que entre a vida e a morte torna-se uma vida impessoal:

O que é imanência? uma vida... Ninguém descreveu melhor que Dickens o que é uma vida, assinalando o artigo indefinido como indício do transcendental. Um canalha, um sujeito ruim, desprezado por todos, é levado moribundo, e de repente aqueles que cuidavam dele manifestam uma certa solicitude, respeito, amor pelo sinal de vida do moribundo. Todos se empenhavam em salvá-lo, de modo que, no ponto mais profundo de seu coma, o vilão sente ele mesmo algo terno invadindo-o. Mas à medida que ele retoma a vida, seus salvadores se tornam mais frios, e ele reencontra toda sua grosseria e maldade. Entre sua vida e sua morte, há 
um momento que é tão-somente o de uma vida que joga com a morte. (Deleuze, 1997, p. 17)

$\mathrm{O}$ indefinido de uma vida como determinação singular. $\mathrm{O}$ momento em que a vida de Riderhood não é mais sua vida, mas uma vida ao mesmo tempo singular e aberta a todos. O sujeito ruim causa compaixão não porque sofre ou porque sua morte parece próxima, mas porque, entre a vida e a morte, ele alcança essa vida impessoal e a representa tão bem que cada um se encontra nela absorvido:

A vida do indivíduo é substituída por uma vida impessoal, embora singular, que produz um puro acontecimento livre dos acidentes da vida interior e exterior, ou seja, da subjetividade e da objetividade do que acontece. (Deleuze, 1997, p. 17)

Texto de grande sabedoria. Estamos diante daquilo que Deleuze chama de hecceidade: não se trata mais de individuação (o indivíduo aqui, no caso o mau sujeito, não existe), porém de singularidade:

Vida de pura imanência, neutra, além do bem e do mal, já que só o sujeito que o encarnava no meio das coisas a tornava boa ou má. A vida de tal individualidade se apaga em benefício da vida singular imanente a um homem que não tem mais nome, embora não se confunda com nenhum outro. Essência singular, uma vida... (Deleuze, 2003, p. 17-18)

\section{Programa/projeto}

É porque a escola coabita com diferenças e singularidades que alguns podem adaptar-se à moral do rebanho; outros devem ter o direito de se rebelar contra um modelo pedagógico pleno de boas intençôes, mas estrangeiro às multiplicidades. $\mathrm{O}$ programa - o oposto do rizoma - impõe a todos a obediência às setas e indicaçōes. $\mathrm{O}$ projeto, diferentemente do programa, experimenta, desconfia das verdades pedagógicas "verdadeiras". Embora o programa tenha sua importância em todo projeto educativo, ele é apenas um instrumento cooptado pelo provisório, molar, identitário. Uma pedagogia molar, uma pedagogia dos arranjos é importante, contudo circunstancial, sua força consiste em aspirar ao molecular. Convém, assim, mudar a relação com o tempo. Não se pode encontrar uma saída se continuarmos a conceber o tempo sob a forma de uma linha reta infinita: é a linha reta infinita que nos ameaça. Faz-se necessário 
se desembaraçar da imortalidade e, acima de tudo, livrar-se da superioridade da alma sobre o corpo (Lins, 2005).

$\mathrm{O}$ que seria uma pedagogia molecular, rizomática? Uma pedagogia da desconstrução e da diferença, do indivíduo como singularidade. Uma pedagogia que não trabalha com formas, mas com encontros nômades, desejos, encruzilhadas e bifurcações.

A educação molar, quando desvinculada do molecular, é, muitas vezes, sustentada pela pedagogia do juízo e da rentabilidade: "ensinar brincando", "otimizar o brincar", "atribuir ao brincar um sentido pedagógico” que amortece a própria força de um brincar que é por definição sempre molecular, isto é, subjetivação, arte do "inútil", por excelência. Puramente lúdico, mas ao mesmo tempo lugar de limites e regras modeladas, remodeladas, pensadas, repensadas, revisitadas, num movimento molar inserido e projetado no molecular, o brincar, como a aprendizagem, é brincar com desejo e não contra o desejo.

As crianças, ao brincarem, inventam suas próprias regras, seus próprios limites; e preparam-se em todos os sentidos para a vida, pura imanência. O brincar é o espaço do possível do pedagógico: "Um pouco de possível senão eu sufoco" parecem dizer, no silêncio, crianças e adolescentes habitados por afectos tristes...

A mobilidade, a leveza do ser, a escuta, o diálogo próprios a uma pedagogia rizomática abrem perspectivas para uma construção de possíveis sob o signo do dom e não apenas da competição que, à força de ocupar o lugar da educação, impõe uma intoxicação das invenções e dos afectos: crianças-suicidas, ou jovens socialmente privilegiados, sofrendo de úlceras precoces, dores de estômago, dores de cabeça, apatia e/ou hiperatividade, a progressão sem limites de processos de somatização, sem justificações aparentes nem solução à vista.

É no processo de criação, alimentado por linhas de fuga, que funciona como campo de uma desterritorialização, isto é, de um partir, de um evadir-se, traçar uma linha, "atravessar o horizonte, penetrar em outra vida” num aprendizado que sabe dizer sim à vida! É essa sem dúvida a força do aprendizado rizomático:

Não ser inferior ao acontecimento, tornar-se o filho de seus próprios acontecimentos (...). Amar os que são assim: quando entram em um lugar, não são pessoas, caracteres ou sujeitos, são uma variação atmosférica, 
uma mudança de cor, uma molécula imperceptível, uma população discreta, uma bruma ou névoa. (Deleuze \& Parnet, 1998, p. 79-80)

A criação, como o devir, é geográfica. Aqui há um problema. Como fazer para que nossos projetos pedagógicos e nossas escolas integrem cada vez mais o devir, a estética da existência? Parafraseando Deleuze, ao enfatizar o caráter arborescente dos franceses, poderíamos dizer que, de fato, nossas escolas são humanas demais, como os franceses, são históricas demais, preocupadas demais com o futuro e com o passado. "Passam seu tempo recapitulando." Até mesmo quanto à escola pensam em um "futuro pedagógico", mais do que em uma antipedagogia do devir ou em um devir a-pedagógico. Nossas escolas parecem ainda não saber "traçar uma linha, seguir um canal. (...) Linha ativa brincando livremente. Passear por passear, sem objetivo particular. Agente: um ponto em movimento" (Deleuze \& Parnet, 1998, p. 50).

Aprender é também aprender a desdobrar as 22 dobras do devirbebê, é perscrutar o silêncio das descobertas, a vida nas dobras, o espaço do dentro:

É em "L'espace du dedans" que Michaux escreve: "A criança nasce com 22 dobras. Trata-se de desdobrá-las. Então a vida de um homem está completa. Sob essa forma ele morre. Não lhe resta nenhuma dobra a desfazer. Raramente um homem morre sem ter ainda algumas dobras a desfazer. Mas acontece". (Deleuze, 1992, p. 139)

A Mangués school, ou a pedagogia nômade, uma espécie de antipedagogia, encontra nas dobras e desdobras movimento para o infinito, projeto aberto aos sopros amorosos e desejos não calcinados.

Experimente, mas é preciso muita prudência para experimentar. Vivemos em um mundo desagradável, onde não apenas as pessoas, mas os poderes estabelecidos, têm interesse em nos comunicar afectos tristes (...). Os poderes estabelecidos têm necessidade de nossas tristezas para fazer de nós escravos. O tirano, o padre, os tomadores de almas, têm necessidade de nos persuadir de que a vida é dura e pesada (...). A questão é a seguinte: que pode um corpo? De que afectos você é capaz? (Deleuze \& Parnet, 1998, p. 75)

Só se experimenta por amor, só se aprende por amor, só se ensina por amor, só se escreve por amor, só se faz amor por amor. É preciso muito trabalho para não viver idiota, para não morrer idiota. Aprender é tam- 
bém aprender a escrever, e a escrita é uma carta de amor. Ora, o amor é da ordem do experimento e não do programa. Experimentar significa também participar ativamente, engajar-se no sentido em que o pensamento não é simplesmente espectador ou contemplador, mas participa de maneira ativa daquilo que tenta. Enfim, na experimentação, o pensamento engaja-se num processo do qual desconhece a saída e o resultado, e é nisso que ele está profundamente vinculado à experiência do novo. $\mathrm{O}$ novo não é a eternidade, é a invenção.

\section{Recebido em maio de 2005 e aprovado em julho de 2005.}

\section{Notas}

1. Afecto em Deleuze, ao contrário do afeto, é uma potência totalmente afirmativa. O afecto não faz referência ao trauma ou a uma experiência originária de perda, segundo a interpretação psicanalítica. O afecto, ao qual nada falta, exprime uma potência de vida, de afirmação, o que aproxima Deleuze de Spinoza: na origem de toda existência, há uma afirmação da potência de ser. Afecto é experimentação e não objeto de interpretação. Neste sentido, afecto não é a mesma coisa que afeto: o afecto é não-pessoal. Nem pulsão nem objeto perdido, "O afecto é uma potência de vida não-pessoal, superior aos indivíduos, o devir nãohumano do homem”. Cf. Lins, 2004a, e o instigante livro de Passetti, 2003.

2. Conceito elaborado por Merleau-Ponty (1964, p. 308), é aqui utilizado em outra concepção e em outro contexto. Un zèro d'etre é para o autor um nada "que se instala à beira do ser (...). Lá onde há múltiplas entradas do mundo que se cruzam”.

\section{Referências bibliográficas}

DAIGNAULT, J. Pour une esthétique de la pédagogie. Victoriaville: NHP, 1985.

DELEUZE, G. Nietzsche et la philosophie. Paris: PUF, 1962a.

DELEUZE, G. Jean-Jacques Rousseau précurseur de Kafka, de Céline et de Ponge. Arts, p.3, 6-12 jun. 1962b.

DELEUZE, G. Le temps musical. (Conferência no IRCAM, Paris, 1978). Disponível em: <http://www.webdeleuze.com/php/texte.php?cle=109\&groupe= Conf\%E9rences\&langue $=1>$.

DELEUZE, G. Diferença e repetição. Trad. Luiz B. L. Orlandi e Roberto Machado. Rio de Janeiro: Graal, 1988. 
DELEUZE, G. Conversaçôes. Trad. Peter Pál Pelbart. São Paulo: Editora 34, 1992.

DELEUZE, G. A imanência: uma vida... In: VAsConcelos, J.; RochA Fragoso, E. (Org.). Gilles Deleuze: imagens de um filósofo da imanência. Londrina: UEL, 1997.

DELEUZE, G. Simulacro e filosofia antiga In: Deleuze, G. Lógica dos sentidos. 4. ed. Trad. Luiz Roberto Salinas Fortes. São Paulo: Perspectiva, 1998. Apêndice 1, p. 259-271.

DELEUZE, G. A dobra, Leibniz e o barroco. 2. ed. Trad. Luiz B. L. Orlandi. Campinas: Papirus, 2000.

DELEUZE, G. À quoi reconnaît-on le structuralisme? In: LAPOUJADE, D. (Ed.). L'île déserte et autres textes. Paris: Minuit, 2002. p. 238-269.

DELEUZE, G.; GUATTARI, F. Kafka: por uma literatura menor. Trad. Julio Castanon Guimarães. Rio de Janeiro: Imago, 1977.

DELEUZE, G.; GUATTARI, F. O que é a filosofia. 2. ed. São Paulo: Editora 34, 1997.

DELEUZE, G.; GUATTARI, F. Mil platôs. Trad. Aurélio Guerra Neto e Célia Pinto Costa. São Paulo: Editora 34, 2000. v.1.

Deleuze, G.; GUATTARI, F. Mil Platôs. Trad. Peter Pál Pelbart e Janice Caiafa. São Paulo: Editora 34, 2002. v.5.

DElEUZE, G.; PARNET, C. Diálogos. Trad. Eloísa Araújo Ribeiro. São Paulo: Escuta, 1998.

DICKENS, C. Our mutual friend. Oxford: Oxford University, 1989.

LAPASSADE, G. L'oeuvre de J. J. Rousseau: structure et unité. Revue de Métaphysique et de Morale, Paris, p. 3, jul.-dez. 1956.

LINS, D. Esquecer não é crime. In: Lins, D.; Gadelha, S.; Veras, A. (Org.). Nietzsche e Deleuze: intensidade e paixão. Rio de Janeiro: Relume-Dumará, 2000. p. 45-62.

LINS, D. Nietzsche e Artaud: por uma exigência ética da crueldade. In: Feitosa, C.; Casanova, M.; De Barrenechea, M.; Dias, R. (Org.). Assim falou Nietzsche III: para uma filosofia do futuro. Rio de Janeiro: 7 Letras, 2001. p. 47-57. 
LINS, D. Juizo e verdade em Deleuze. São Paulo: Annablume, $2004 a$.

LINS, D. Les signes corporels des Amérindiens d'Amazonie. In: FaLAgayrettes-Leveau (Org.). Les signes du corps. Paris: Musée Dapper, $2004 \mathrm{~b}$. p. 249-258.

LINS, D. Justiça e desejo (falar não é ver). In: PAssetti, E. (Org.). Kafka e Foucault sem medos. São Paulo: Ateliê, 2004c. p. 103-114.

LINS, D. A expressão: Spinoza em Deleuze/Deleuze em Spinoza. São Paulo: Ateliê, 2005.

LYOTARD, J.-F. Rudiments Pä̈ens. Paris: UGE, 1997.

MEIRIEU, P. Frankenstein pedagogue. Paris: ESF, 1996.

MEIRIEU, P.; DEVELAY, M. Émile, reviens vite, ils sont devenus fou. Paris: ESF, 1992.

MERLEAU-PONTY, M. Le visible et l'invisible. Paris: Gallimard, 1964.

PASSETTI, E. Ética dos amigos: invenções libertárias da vida. São Paulo: Imaginária, 2003.

RANCIÈRE, J. Entretien avec Jacques Rancière. Dissonance, v. 1, abr. 2004. Disponível em: <http://www.messmedia.net/dissonance/index.htm>. Acesso em: 24 jan. 2005.

SimONDON, G. A gênese do indivíduo. In: Pelbart, P.P.; Costa, R. (Org.). O reencantamento do concreto. São Paulo: Hucitec, 2003. p. 97-118. 